Marquette University

e-Publications@Marquette

Biomedical Sciences Faculty Research and

Publications

Health Sciences, College of

$12-23-2016$

Selecting Optimal Combinations of Transcription Factors to Promote Axon Regeneration: Why Mechanisms Matter

Ishwariya Venkatesh

Marquette University

Murray G. Blackmore

Marquette University, murray.blackmore@marquette.edu

Accepted version. Neuroscience Letters (December 23, 2016). DOI. (C) 2016 Elsevier Ireland Ltd. Used with permission. 


\title{
Selecting Optimal Combinations of Transcription Factors to Promote Axon Regeneration: Why Mechanisms Matter
}

\author{
Ishwariya Venkatesh \\ Department of Biomedical Sciences, Marquette University, \\ Milwaukee, WI \\ Murray G. Blackmore \\ Department of Biomedical Sciences, Marquette University, \\ Milwaukee, WI
}

\begin{abstract}
Recovery from injuries to the central nervous system, including spinal cord injury, is constrained in part by the intrinsically low ability of many CNS neurons to mount an effective regenerative growth response. To improve outcomes, it is essential to understand and ultimately reverse these neuronintrinsic constraints. Genetic manipulation of key transcription factors (TFs), which act to orchestrate production of multiple regeneration-associated genes, has emerged as a promising strategy. It is likely that no single TF will be sufficient to fully restore neuron-intrinsic growth potential, and that multiple, functionally interacting factors will be needed. An extensive literature, mostly from non-neural cell types, has identified potential
\end{abstract}


NOT THE PUBLISHED VERSION; this is the author's final, peer-reviewed manuscript. The published version may be accessed by following the link in the citation at the bottom of the page.

mechanisms by which TFs can functionally synergize. Here we examine four potential mechanisms of TF/TF interaction; physical interaction, transcriptional cross-regulation, signaling-based cross regulation, and cooccupancy of regulatory DNA. For each mechanism, we consider how existing knowledge can be used to guide the discovery and effective use of TF combinations in the context of regenerative neuroscience. This mechanistic insight into TF interactions is needed to accelerate the design of effective TFbased interventions to relieve neuron-intrinsic constraints to regeneration and to foster recovery from CNS injury.

Keywords: Transcription factor, Axon regeneration, Co-occupancy, Combination, Network, Spinal cord injury

\section{Introduction}

Coaxing robust, long distance regeneration from injured neurons remains a major unmet challenge in the treatment of spinal cord injury. Although extrinsic barriers to axon regeneration contribute, cell-intrinsic mechanisms within injured CNS neurons also limit axon growth. ${ }^{10}$ and 17 Axon extension requires a profound change in cellular state within injured neurons. Prior to axotomy, neurons are tasked with maintaining intracellular communication and structural homeostasis in far-flung processes; after axotomy, regeneration demands the production, transport, and regulated assembly of enormous amounts of cytoskeletal and membranous material. The sheer number of genes that must be up- or down-regulated to reinitiate axon extension presents a major challenge to targeting the neuron-intrinsic growth state. ${ }^{10,47}$ One possible solution is that underlying transcription factors (TFs) might be manipulated in injured neurons, perhaps acting as simple levers to alter the expression of large numbers of downstream regeneration-associated genes (RAGs). A growing number of TFs have been functionally linked to axon growth in a variety of cell types (Table 1 ). Indeed, manipulation of TFs including KLFs, SOX11, and STAT3 has enhanced regenerative axon growth after spinal injury.11,37,85 On the other hand, the number and regenerative speed of treated axons likely remains well below the threshold for functional recovery.

Table 1. Summary of regeneration associated TFs (RAG TFs) shown to regulate axon growth in vivo.

\section{Regeneration associated TFs}

Model of regeneration

Sciatic nerve crush
References

Seijjfers et al $^{67}$

Neuroscience Letters, (December 2016). DOI. This article is (C) Elsevier and permission has been granted for this version to appear in e-Publications@Marquette. Elsevier does not grant permission for this article to be further copied/distributed or hosted elsewhere without the express permission from Elsevier. 
NOT THE PUBLISHED VERSION; this is the author's final, peer-reviewed manuscript. The published version may be accessed by following the link in the citation at the bottom of the page.

\begin{tabular}{lll}
\multicolumn{1}{c}{$\begin{array}{c}\text { Regeneration } \\
\text { associated TFs }\end{array}$} & \multicolumn{1}{c}{ Model of regeneration } & \multicolumn{1}{c}{ References } \\
cJUN & $\begin{array}{l}\text { Facical nerve transection } \\
\text { Sciatic nerve crush }\end{array}$ & $\begin{array}{l}\text { Raivich et al. }{ }^{65} \\
\text { Saijilafu et al. }{ }^{66}\end{array}$ \\
CREB & Conditioning lesion & Gao et al. ${ }^{27}$ \\
KLF7 & Pyramidotomy and cervical & Blackmore et al. ${ }^{11}$ \\
& SCI & \\
HIF1alpha & Sciatic nerve crush & Cho et al. ${ }^{16}$ \\
MYC & Optic nerve injury & Belin et al. ${ }^{6}$ \\
MASH1 & Thoracic SCI & Williams et al. ${ }^{87}$ \\
p53 & Facial nerve axotomy & Tedeschi et al. ${ }^{78}$ \\
SMAD1 & Thoracic SCI & Parikh et al. ${ }^{62}$ \\
SOX11 & Saphenous nerve crush & Jankowski et al. ${ }^{35}$ \\
& Pyramidotomy and cervical & Wang et al. ${ }^{85}$ \\
& SCI & \\
KLF4 & Optic nerve injury & Moore et al. ${ }^{56}$ \\
STAT3 & Saphenous nerve crush & Bareyre et al. ${ }^{5}$ \\
& Dorsal column transection- & \\
& DRGs & \\
& Unilateral pyramidotomy & Lang et al., $2013^{42}$ \\
& Optic nerve injury & Smith et al., Luo et al. ${ }^{49,69}$
\end{tabular}

One explanation for this limited response may be that no single TF is sufficient to drive a full regenerative program. Instead, groups of functionally interacting factors are likely needed, similar to the situation in induced pluripotency. ${ }^{74}$ Indeed, recent work in the optic system makes it plain that combinatorial gene manipulations are most effective in producing axon regeneration. ${ }^{6,49,73}$ Although plausible in principle, this combinatorial perspective brings with it the challenge of identifying optimal sets of TFs. ${ }^{77,79}$ With well over one thousand TFs in the genome and at least a dozen already linked to regenerative axon growth in vivo ( Table 1), the number of possible combinations is daunting.

Here we argue that optimal selection of pro-regenerative TF combinations requires careful consideration of the underlying mechanisms of interaction. Fundamentally, the specifics of the various molecular interactions between TFs have profound implications for the discovery and eventual use of TF combinations to improve regenerative axon growth. To illustrate this, we briefly consider four general mechanisms by which TFs can functionally interact. For the sake of clarity, we frame the discussion around two-way interactions

Neuroscience Letters, (December 2016). DOI. This article is (C) Elsevier and permission has been granted for this version to appear in e-Publications@Marquette. Elsevier does not grant permission for this article to be further copied/distributed or hosted elsewhere without the express permission from Elsevier. 
between factors, with the understanding that this basic framework must eventually be scaled to accommodate multi-factor networks. For each mechanism we 1 ) examine instances in which the mechanism has been demonstrated in TFs linked to axon growth 2) examine how the mechanism informs improved discovery of TF/TF interactions and 3) consider the implications of the mechanism for optimal comanipulations. This consideration of the details of TF/TF interactions is critical to accelerate the discovery of optimal TF mixtures and improve the efficacy of combinatorial manipulations.

\section{Physical interaction}

TFs can directly bind to one another and reciprocally influence activity (Fig. 1). Indeed, some families of TFs, notably bZIP, bHLH, and STATs, are obligate dimers; the ability to bind DNA is conferred by the presence of two subunits [reviewed in ${ }^{2}$ ]. Obligate dimers form both homo- and heterodimers, commonly with related family members. Importantly, transcriptional activity can be increased or suppressed depending on the specific partnerships formed, creating a system for graded control of transcription. A highly relevant example involves the bZIP AP1 factors, JUN and ATF3. Previous work indicates that JUN homodimers drive moderate activation of target genes and JUN-ATF3 heterodimers drive strong activation, whereas ATF3 homodimers can act to repress transcription. ${ }^{4}$ JUN and ATF3 have been individually linked to axon regeneration, ${ }^{65,67}$ and single overexpression of each has been attempted to enhance regenerative outcomes. Intriguingly, it was recently shown that forced co-expression of both factors is more effective in promoting axon growth in sensory neurons than either alone. ${ }^{13}$ These data raise the possibility that the synergistic effects of co-expressed JUN and ATF3 in sensory axon growth might be explained by direct binding, although this possibility has yet to be directly tested. 
NOT THE PUBLISHED VERSION; this is the author's final, peer-reviewed manuscript. The published version may be accessed by following the link in the citation at the bottom of the page.

\begin{tabular}{|c|c|c|}
\hline Interactive Mechanism & Discovery methods & Implications \\
\hline Physical Interaction & $\begin{array}{l}\text { - Immunopreciptation } \rightarrow \text { Mass } \\
\text { spec } \\
\text { - PPI Databases (StringdB, } \\
\text { TRRUST, MINT, BioGRID, IntAct) }\end{array}$ & $\begin{array}{l}\text { - Need for controlled } \\
\text { stoichiometry } \\
\text { - Potential utility of tethered } \\
\text { constructs }\end{array}$ \\
\hline Transcriptional Cross-regulation & $\begin{array}{l}\cdot \text { RNAseq } \rightarrow \text { ChIP-Seq } \\
\cdot \text { Ingenuity pathway analysis } \\
\text { (IPA) } \\
\text {-TRRUST } \\
\end{array}$ & $\begin{array}{l}\text { - Hierarchical relationships help } \\
\text { prioritize TF selection } \\
\text { - Identify and dampen } \\
\text { homeostatic production of } \\
\text { growth-suppressive TF }\end{array}$ \\
\hline $\begin{array}{c}\text { Signaling Cross-regulation } \\
\text { Signaling intermediate } \\
\text { promoter }\end{array}$ & $\begin{array}{l}\text { - Monitor } \\
\text { abundance/activity of } \\
\text { upstream TF regulators } \\
\text {-IPA } \\
\text { - TRANSPATH }\end{array}$ & $\begin{array}{l}\text { - Rational TF/pharmacological } \\
\text { combinations } \\
\text { - Selection of mutant TFs to } \\
\text { amplify or dampen signaling } \\
\text { effects }\end{array}$ \\
\hline Co-occupancy & $\begin{array}{l}\text { - Combinatorial ChIP-Seq } \\
\text { - ENCODE } \\
\text { - ReMap } \\
\text { - VISTA enhancer browser } \\
\text { - NIH epigenome roadmap }\end{array}$ & $\begin{array}{l}\text { - Selection of TFs with } \\
\text { complementary epigenetic } \\
\text { functions to maximize synergy } \\
\text { - Importance of timing / correct } \\
\text { sequence of expression }\end{array}$ \\
\hline
\end{tabular}

Fig. 1. Transcription factors functionally interact through distinct mechanisms. The left-hand column illustrates four potential mechanisms of TF/TF interaction. The middle column lists experimental techniques and bioinformatics resources that can be used to identify each mechanism. The right-hand column lists the implications of each mechanism for optimizing the use of multiple TFs for maximal effect.

In addition to obligate dimers, physical interaction between TFs is also common across TF classes, and between TFs that normally function as individual subunits (e.g. zinc finger TFs). In one highly relevant example from optic nerve regeneration, KLF4, which acts to inhibit axon growth in this system, physically associates with and inhibits pro-regenerative STAT3 (Qin et al.). In addition, a wide range of physical interactions between RAG TFs, shown mostly in non-neural cell types, are summarized in Fig. 2 (references provided as hyperlinks in Supplementary Table S1). Notably, p53 (TP53) can bind seven of the twelve RAG TFs (STAT3, KLF6, MYC, ATF3, CREB, HIF1A, SMAD1), and STAT3 binds five (KLF4, ATF3, SMAD1, p53, HIF1A). In summary, although data in neurons remain sparse, evidence from non-neural cell types strongly supports the possibility that TFs implicated in regeneration may influence one another's activity in part through direct physical association.

Neuroscience Letters, (December 2016). DOI. This article is (c) Elsevier and permission has been granted for this version to appear in e-Publications@Marquette. Elsevier does not grant permission for this article to be further copied/distributed or hosted elsewhere without the express permission from Elsevier. 
NOT THE PUBLISHED VERSION; this is the author's final, peer-reviewed manuscript. The published version may be accessed by following the link in the citation at the bottom of the page.

A

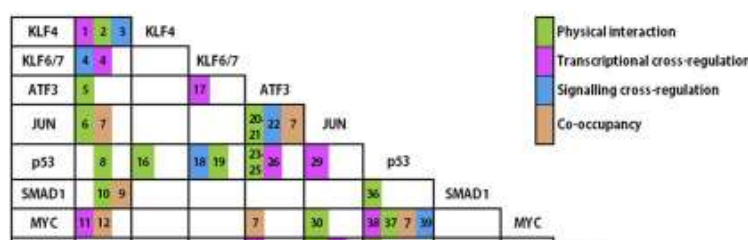

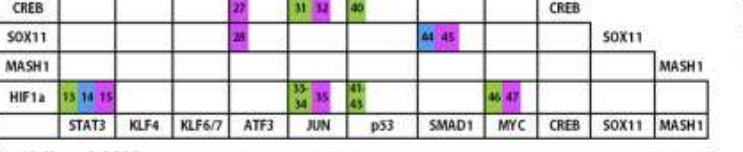

1 Hall et al, 2009

2 Qinet al., 2013

10 Nakashimaet al

3 Qin and Zhang,2012 11 Valera et al, 2013

4 Laitman et al,,2016 12 Kidder et al, 2008

5 Grossman et al, 201513 Gray et al.2005

6 Zhanget al,1999 14 Jiang et al,2013

7 Griffonet al,2015 15 Marzecet al, 2011

8 Parketal, 2013

16 Zhang et al, 2000
17 Huanget al, $2008 \quad 25$ Stelzl et al, 2005

18 Tarocchietal,2011 26 Zhang et al, 2002

19 Rubensteinet al, 200. 27 Zhang et al, 2011

20 Liet al, 2015

22 Kimet al, 2014

23 Yanet al, 2005

24 Yanet al, 2002

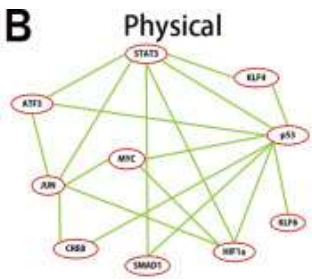

D Signaling

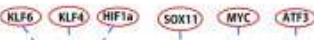

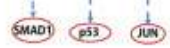

33 Yu et al, 2009

34 Alfranca et al.,2002

35 Laderoute et al, 2002

36 Chau et al, 2012

37 Agarwalet al, 2010

30 Levy and Forman,2010 38 Ben-Yosef et al, 1998
31 Benbrook and bnes, $1990 \quad 39$ Slack et al,_2005

31 Benbrook and tones, 199039 Slack et al, 2005
32 Herdegen and Leah, $1998 \quad 40$ Giebler et aL,2000

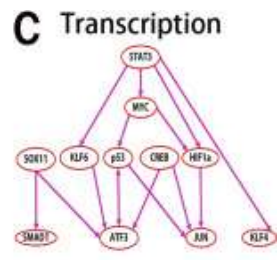

E Co-occupancy

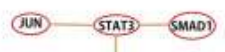

(ATF3) (MNC) (PS3)

41 Bae et al, 2002

42 Sanchez-puig et al, 2005

43 Anet al. 1998

44 Xu et al, 2015

45 Vegliante et al, 2013

45 Koshijiet al,2004

47 Doe et al, 2012

Fig. 2. Existing data establishes functional interactions between regenerationassociated transcription factors. (A) Identified interactions between RAG-TFs are categorized by mechanism, indicated by color, and by numbers to indicate the source reference, below. References are provided as hyperlinks in Supplementary Table S1. (B-E) Existing databases were used to identify interactions between RAG-TFs. STRINGdB identified physical binding between TFs (B), TRRUST identified transcriptional hierarchies (C), TRANSPATH and IPA identified cross-regulation through signaling intermediates (D), and combined IPA, literature mining, and ENCODE data identified factors that co-occupy regulatory DNA regions (E).

\subsection{Implications for discovery}

Physical binding between TFs is perhaps the most straightforward type of interaction to identify. Datasets and network tools that include physical interactions, although built largely from non-neural cell types, ${ }^{14,24,31,44,60}$ are readily available and are already being used to help prioritize TFs of interest in the context of regeneration research. ${ }^{13,77,79} \mathrm{~A}$ driving assumption of this approach is that TFs with large numbers of known interactions act as hub proteins and are thus high priority targets for functional intervention. Although certainly valid, an important caveat to this assumption is that the number of known physical interactions for each TF is highly influenced by the interest that TF has previously received, mostly in non-neural cell types. For example, a Pubmed search for p53 identifies $>80,000$ manuscripts, STAT3 identifies $>15000$, and a search for KLF6 yields less than 400 . Thus it is perhaps unsurprising that the number of known interactions with other RAG TFs is higher for p53 and STAT3. When extrapolating available network data to prioritize TFs for regenerative axon growth, care must to taken to avoid a self- 
reinforcing interest in well-studied factors, at the expense of TFs that may be less well studied but functionally important.

Unbiased methods are available to discover physical interactions between TFs. For example, novel TF binding partners can be identified by proteomic analysis involving immunoprecipitation with mass spectrometry. ${ }^{28}$ In a complementary approach, the spatial distribution of TF binding in the genome can be used to predict possible physical interactions. ${ }^{82}$ First, chromatin immunoprecipitation and high throughput sequencing (ChIP-Seq) can be used to determine genomewide locations of binding by TFs of interest. Then, bioinformatic tools are used to scan adjacent sequences for recognition motifs of potential partner TFs, with particular attention paid to promoter and enhancer regions for genes of interest, in this case, regeneration-associated genes. If two TFs bind one another and then additionally bind DNA, this can be detected in TF binding sites in very close proximity. Software packages are now available for this approach. ${ }^{50}$ In this way, starting from a TF that is known to promote regeneration, it would be possible to identify other TFs that commonly bind, which would act to prioritize candidate TFs in subsequent co-expression functional tests.

\subsection{Implications for functional intervention}

The prevalence of TF/TF interactions at the protein level raises important considerations of stoichiometry. The importance of TF stoichiometry is well established for efficient cellular reprogramming, ${ }^{58}$ and it is likely that efforts to improve axon growth by delivery of multiple TFs will similarly depend on optimal ratios of co-expression. For example, the observation that JUN-ATF3 heterodimers have been shown to drive strong transcriptional activation, while ATF3 homodimers act to repress transcription, raises the possibility that the phenotypic effects of forced co-expression will vary according to the relative levels. An excess of ATF3 over JUN could facilitate homodimer formation, tilting the balance toward repression. This issue is significant because in most standard methods of gene delivery (e.g. plasmid transfection or viral delivery) the level of protein production is quite variable and difficult to control. In this way, experimental tests of forced co-expression could miss possible ratio-specific synergies. It is even possible that uncontrolled stoichiometry might help explain

Neuroscience Letters, (December 2016). DOI. This article is (C) Elsevier and permission has been granted for this version to appear in e-Publications@Marquette. Elsevier does not grant permission for this article to be further copied/distributed or hosted elsewhere without the express permission from Elsevier. 
differences in the reported efficacy of JUN/ATF3 co-expression in promoting sensory axon growth. ${ }^{13,22}$

One possible solution to achieve more controlled stoichiometry is polycistronic expression of multiple factors from the same construct. If approximately equivalent levels of two TFs is desired, a 2A-peptide approach can be utilized. ${ }^{11,75}$ In this way, although individual cells will still receive varying levels of TFs, the ratio of the two will be much more consistent. Alternatively, a dual promoter design in which each TF is under the control of a different promoter, could enable skewed ratios by selecting promoters with differing levels of activity in the cell type of interest. ${ }^{48}$ In addition, when the optimal ratio is unknown, it should also be possible to take advantage of inducible promoters to systematically vary the production of exogenously expressed TFs. For example, it was recently found using a Tet-on plasmid and varying levels of doxycyclin that the growth-promoting effects of HIF1A are concentration dependent. ${ }^{16}$ This approach could be extended to dualoverexpression experiments to systematically test a range of expression ratios. Finally, in situations in which particular TF-TF binding is desired, so-called "tethered" constructs can be constructed in which two TFs are produced as a single protein, with the two units linked by a flexible amino acid tether. This strategy has been used to force interactions that favor motorneuron development, ${ }^{26}$ and notably, has been used to force Jun/ATF3 cooperativity. ${ }^{4}$ Thus when contemplating co-expression of pro-regenerative TFs that can potentially physically interact, similar strategies to control stoichiometry and association should be considered.

An additional complication is the potential for extra-nuclear activities by TFs. One prominent example is STAT3, which in addition to the nucleus, is also known to localize to the cytoplasm and mitochondria in CNS neurons. ${ }^{49,68,92}$ In early embryonic spinal motorneurons, growth-promoting effects of cytoplasmic STAT3 are largely independent of transcription, ${ }^{68}$ driven instead by axonal STAT3 stabilizing microtubules. In adult retinal ganglion cells, viral treatment of mitochondrial STAT3 along with constitutively-active STAT3 was more effective in promoting optic nerve regeneration than either treatment alone. ${ }^{49}$ Therefore, it is important to consider potential nonnuclear localization of RAG TFs when overexpressed, which could variably impact axon regeneration. One approach to do so involves

Neuroscience Letters, (December 2016). DOI. This article is @ Elsevier and permission has been granted for this version to appear in e-Publications@Marquette. Elsevier does not grant permission for this article to be further copied/distributed or hosted elsewhere without the express permission from Elsevier. 
conventional cloning techniques and the overexpression of DNAbinding mutants or the addition of nuclear localization signals (NLS) or Nuclear export signals (NES). ${ }^{49}$ Alternatively, recent advances in synthetic biology allow for precise and reversible control of nuclear translocation of proteins in response to light-stimulation, a potentially powerful approach to distinguish nuclear from extra-nuclear functions of TF proteins. ${ }^{86}$

\section{Transcriptional cross-regulation}

Transcription factors can potentially elevate or suppress the transcription of "downstream" TFs by directly targeting relevant promoter or enhancer regions (Fig. 1). In this model, an early wave of TFs important for axon growth could potentially act to initiate secondary cascades of additional pro-regenerative TFs. Alternatively, pro-regenerative TFs might also trigger homeostatic mechanisms in which they activate expression of TFs that then act to limit regeneration.

The focus here is on direct transcriptional regulation between TFs, which requires stringent experimental evidence. A continuum of experimental approaches provide varying degrees of certainty for direct transcriptional regulation. Correlative experiments, in which forced expression or knockdown of one TF leads to a change in expression of a second, hint at transcriptional cross-regulation but can't distinguish direct transcriptional activation from indirect consequences of downstream effector proteins. For instance, in sensory neurons responding to peripheral injury, knockdown of SOX11 leads to reduced ATF3 expression, and in oligodendrocyte precursor cells, activation of STAT3 leads to elevated transcription of KLF6. ${ }^{35,41}$ These data hint at transcriptional cross-regulation, but a mechanism of direct transcriptional regulation was not established.

To make a strong case for direct transcriptional regulation, two additional types of data are needed. First is evidence for binding of a TF to the regulatory region(s) of the putative target TF. This evidence can be purely predictive, such as scanning promoter/enhancer sequences for canonical TF binding motifs, can involve in vitro binding (e.g. gel shift mobility assays), or can be performed in vivo (chromatin immunoprecipitation- ChIP). ChIP provides the strongest evidence for

Neuroscience Letters, (December 2016). DOI. This article is (C) Elsevier and permission has been granted for this version to appear in e-Publications@Marquette. Elsevier does not grant permission for this article to be further copied/distributed or hosted elsewhere without the express permission from Elsevier. 
binding, although it must be kept in mind that binding of TFs to specific genomic loci is highly cell-type specific. ${ }^{28}$ Second, after binding is established, functional evidence for transcriptional regulation by TF binding (e.g. luciferase assays) is also needed. In general, strong evidence for the ability of RAG TFs to bind and regulate other TFs is scarce in neurons, but can be found in other cell types (Fig. 2 and Supplementary Table S1). Intriguingly, STAT3 transcriptionally regulates 4 other RAG TFs, KLF6, KLF4, MYC, and HIF1A (Fig. 2C). Three of these STAT3 targets in turn transcriptionally regulate additional downstream RAG TFs, hinting at a potential transcriptional hierarchy among RAG TFs. In addition, p53 binds the ATF3 promoter and activates transcription, while ATF3 binds and represses the p53 promoter, suggesting a loop of feedback inhibition. ${ }^{38,90}$ These data hint that similar transcriptional relationships between RAG TFs may regulate axon growth.

\subsection{Implications for discovery}

In principle, transcriptional relationships between RAG TFs should be relatively straightforward to identify. Initial analyses would involve transcriptional profiling of neurons after forced expression or knockdown of one RAG TF, in order to determine whether the expression of other RAG TFs changes in response. Follow-up motif analysis of promoter/enhancer regions, ChIP, and expression assays (e.g. luciferase) could then rule in or out direct transcriptional relationships. Indeed, this discovery workflow has been applied to single target genes in regenerating neurons, ${ }^{31,78}$ and genome-wide in a variety of non-neural cells (See Fig. 2, Supplementary Table S1, and ${ }^{41}$ ). These transcriptional relationships are described in searchable databases including IPA and TRRUST ${ }^{31,79}$ and raise the possibility that similar relationships may exist in neurons. In summary, genome-wide discovery efforts focused on neurons and targeted verification of predicted transcriptional relationships offer a rapid way to expand knowledge of TF networks in regenerative neuroscience.

\subsection{Implications for functional intervention}

Greater clarity regarding transcriptional relationships between RAG TFs would be quite useful in two ways. First, clarifying TF

Neuroscience Letters, (December 2016). DOI. This article is @ Elsevier and permission has been granted for this version to appear in e-Publications@Marquette. Elsevier does not grant permission for this article to be further copied/distributed or hosted elsewhere without the express permission from Elsevier. 
cascades and hierarchical relationships in regeneration would assist in selecting top-level TFs that can drive secondary expression of additional TFs for maximal effect. In one simple example, if the observation that STAT3 activation leads to elevated KLF6 expression (above) holds true in a neuronal context, this information would prioritize STAT3 interventions for combinatorial gain. As hierarchical cascades are clarified, perhaps a relatively small set of core TFs could be identified whose expression might achieve widespread activation of a larger cohort of needed TFs. Second, knowledge of transcriptional hierarchies might help avoid unintended and counter-productive consequences of TF interventions. Indeed, it is clear that proregenerative TFs can engage homeostatic mechanisms that ultimately dampen their pro-regenerative activities. One well-studied example involves STAT3, which upregulates the expression of SOCS3, which in turn represses STAT3 activity. Genetic deletion of SOCS3 is now a well-established means to enhance STAT3 activity. ${ }^{73}$ By analogy, it is conceivable that pro-regenerative TFs engage homeostatic transcriptional mechanisms that act to repress expression of other RAG TFs; such a relationship is hinted at by the upregulation of KLF4, a growth-repressive TF, by STAT3. ${ }^{30}$ Identifying such homeostatic circuits, and devising ways to circumvent them, may amplify net proregenerative effects. In summary, increased information regarding transcriptional relationships between pro-regenerative factors will facilitate combinatorial strategies that are maximally efficient by favoring top-level factors, and which may help avoid unintended (negative feedback) consequences of TF intervention.

\section{Cross-activation through downstream effectors}

The activity of TFs is controlled not only by abundance, but also through a variety of post-translational modifications and the availability of co-factors. Thus, in addition to the direct transcriptional relationships considered above, TFs can influence one another's activity indirectly by altering the expression of upstream regulators of a second TF (Fig. 1C). For example, KLF factors do not appear to alter STAT3 expression, but may influence STAT3 activity through upstream regulators. Specifically, in oligodendrocyte precursor cells, KLF6 binds and activates the promoter region of gp130, a cytokine receptor, which in turn elevates JAK signaling and STAT3 activation. ${ }^{41}$ Similarly,

Neuroscience Letters, (December 2016). DOI. This article is @ Elsevier and permission has been granted for this version to appear in e-Publications@Marquette. Elsevier does not grant permission for this article to be further copied/distributed or hosted elsewhere without the express permission from Elsevier. 
in neural stem cells, KLF4 transcriptionally activates cytokine receptors and JAK3, leading to STAT3 phosphorylation and activation. ${ }^{77}$ In adipocytes, HIF1A also affects STAT3 activity through transcriptional activation of SOCS3, an inhibitor of STAT3 signaling. ${ }^{36}$ In mesenchymal stem cells, SOX11 transcriptionally increases expression of BMP receptors, which leads to activation of SMAD1. ${ }^{68}$ In hepatic tumors, KLF6 transcriptionally represses MDM2, a major inhibitor of p53, and thus acts to increase p53 activity. ${ }^{76}$ Additional examples can be found in Fig. 2 and Supplementary Table S1, illustrating widespread occurrence of TF cross regulation through signaling mechanisms.

\subsection{Implications for discovery}

For RAG TFs with regulatory PTMs that are well established and readily detectable (e.g. effective phospho-specific antibodies), signaling cross-talk from other TFs is relatively easy to detect. For example, the activity of STAT3, SMAD1, and JUN are all known to be controlled in part by phosphorylation, and phospho-specific antibodies exist for all three. Thus, forced expression or knockdown of a battery of RAG TFs could be followed by assessment of changes in phosphorylation state. Similarly, when upstream regulators of TFs are known (e.g. MDM2 as a well-established repressor of p53 activity, or SOCS3 as a STAT3 inhibitor), the abundance of these regulators can be readily monitored after manipulation of other TFs. The situation is much more challenging, however, for TFs such as SOX11 and KLFs. Although some information regarding KLF phosphorylation and acetylation is available, there remains a dearth of knowledge regarding upstream regulators of activity for these zinc finger factors. ${ }^{3,57}$ Thus for some factors, detection of TF-TF interactions via signaling cross-talk awaits more information regarding regulatory modifications and the development of PTM-specific antibodies.

\subsection{Implications for functional intervention}

Perhaps the most important implication of signaling-based cross-talk between TFs is the possibility that such cross-regulation might could be mimicked or blocked by pharmacological agents. That is, if functional synergy between two TFs results in part from the ability of one factor to activate another TF through signaling

Neuroscience Letters, (December 2016). DOI. This article is (C) Elsevier and permission has been granted for this version to appear in e-Publications@Marquette. Elsevier does not grant permission for this article to be further copied/distributed or hosted elsewhere without the express permission from Elsevier. 
intermediates, (e.g. JAKs or JNKs), then pharmacological activation of these intermediates may amplify the synergy. In addition, as discussed above regarding transcriptional relationships, proregenerative TFs may engage homeostatic growth-suppressive signaling mechanisms. In that scenario, pharmacological inhibition of these pathways might increase net growth promotion. Finally, whether the goal is to amplify or dampen downstream signaling cascades that link TFs, an alternative to pharmacology is forced expression of mutant TFs that mimic or prevent the relevant modifications (e.g. phosphormimic or -null mutants). As one example, if KLF6 leads to elevated STAT3, then perhaps this effect might be amplified by expression of constitutively active STAT3 mutations. ${ }^{49}$ Thus, increased understanding of signaling cascades affected by TF expression is important for regenerative neuroscience by guiding the rational development of TF modifications and potential combination with pharmacological agents.

\section{Co-occupancy of regulatory DNA}

Gene transcription is regulated by the binding of TFs to cisregulatory DNA sequences. These elements are often conceptually divided into short-range elements such as promoter regions, found within $1 \mathrm{kB} 5^{\prime}$ to transcriptional start sites, and long-range regulatory elements such as enhancer regions that can influence transcription from locations as far as $100 \mathrm{~s}$ of $\mathrm{Kb}$ in either the $5^{\prime}$ or $3^{\prime}$ direction. Although data from neurons remains limited, extensive ChIP-based profiling datasets have emerged for a range of TFs in a variety of cell types, creating an increasingly clear picture of genome-wide binding. For example, the ENCODE project has generated genome-wide ChIPSeq data for more than $100 \mathrm{TFs}$, complemented by genome-wide profiling of chromatin accessibility and epigenetic modifications. These integrated datasets allow powerful correlative analysis between TF binding location, chromatin status and accessibility, and expression at loci across the genome. ${ }^{83} \mathrm{~A}$ key insight to emerge from these datasets is that transcription is rarely predicted by the binding of any single factor, but rather reflects binding by multiple TFs to both promoter and enhancer elements. For example, in developing erythrocytes, cooccupancy by three TFs, TAL1, GATA1, and SMAD1, proved to be a predictor of enhancer activity with a remarkable $80 \%$ accuracy; single binding by any one factor was much less predictive. ${ }^{20}$ Similarly,

Neuroscience Letters, (December 2016). DOI. This article is @ Elsevier and permission has been granted for this version to appear in e-Publications@Marquette. Elsevier does not grant permission for this article to be further copied/distributed or hosted elsewhere without the express permission from Elsevier. 
genome-wide binding by more than 100 TFs, generated by the ENCODE project, was analyzed for co-occupancy by TFs. Interestingly, when considering genes whose expression is highly cell-type specific, the cells in which transcription selectively occurred were marked by binding of between 8 and 12 distinct factors to the promoter region, whereas non-expressing cell types showed binding by zero to three factors. Again, occupancy by multiple TFs, and no single TF, predicts expression. ${ }^{82}$

A variety of mechanisms can explain additive or synergistic transcriptional effects of co-occupancy. One possibility is that two factors interact with different, widely separated regulatory regions. For example, one TF may bind a proximal promoter but confer minimal transcriptional activation until a second TF binds and activates a distal enhancer. Other mechanisms depend on co-occupancy of different TFs in close proximity on the same promoter or enhancer. Recruitment of multiple TFs may facilitate activation by leading to non-linear gains in nucleosome displacement, ${ }^{54,81}$ by enhancing the association of coactivators such as p300 (transcriptional synergy), 53 initiation of local DNA bending by TFs (eg HMG1) which may increase the affinity for other TFs. ${ }^{23,55}$ In all cases, the critical point is that co-occupancy models indicate that TFs can profoundly influence one another's transcriptional output without necessarily engaging in direct binding or reciprocal regulation of abundance/activity (Fig. 1D).

\subsection{Implications for discovery}

Most fundamentally, the potential for functional interaction through co-occupancy means that in the search for functional combinations of TFs to promote axon growth, sole reliance on proteinprotein and transcriptional relationships may fail to detect important network members. Analysis of the spatial relation of TF binding sites provides an alternative means to uncover possible co-regulators. This strategy involves 1) genome-wide analysis of binding by TFs of interest in a relevant cell type and 2) scanning of nearby or functionally grouped sequences (e.g. disparate enhancers that regulate a common gene) for statistically over-represented binding motifs of other TFs. An illustrative example comes from the study of motorneuron development. Starting from previous observations that

Neuroscience Letters, (December 2016). DOI. This article is @ Elsevier and permission has been granted for this version to appear in e-Publications@Marquette. Elsevier does not grant permission for this article to be further copied/distributed or hosted elsewhere without the express permission from Elsevier. 
an LHX1-ISL1 tethered construct promotes MN differentiation, Lee et al. performed ChIP-Seq analysis to identify several thousand binding sites in differentiating stem cells. ${ }^{43}$ Motif analysis revealed that $80 \%$ of these sites were in close proximity to predicted binding sites for STAT3, suggesting a previously unknown cooperative role. Indeed, follow-up experiments revealed an important functional requirement for STAT3 in recruitment of the LHX1-ISL1 construct and MN differentiation. The basic strategy of using genome-wide occupancy data to discover new members of TF regulatory networks has been employed with great effect in the study stem cell differentiation, 59 cancer biology, ${ }^{89}$ hematopoetic differentiation ${ }^{29}$ and more. In addition, an integrated analysis of TF ChIP-seq data from multiple cell types mapped a co-occupancy matrix for more than 100 TFs, including 7 RAG TFs. These analyses reveal intriguing examples of co-occupancy by RAG TFs, including nearly $50 \%$ co-occupancy by STAT3 with both MYC and JUN (Fig. 2).

What is needed to employ a similar strategy in regenerative neuroscience? First, and most fundamentally, the requisite ChIP-Seq datasets must be created. In comparison to other fields (above) regenerative neuroscience has made little progress in developing datasets of genome-wide binding by RAG TFs in relevant cell types (e.g. regenerating peripheral neurons or early developmental CNS neurons). TF binding patterns can change dramatically between cell types and even within a single cell type across development, 7,25,28 Nevertheless, ChIP-seq datasets are available for RAG TFs in the context of neural differentiation (SOX117) and in adult activitydependent plasticity (AP1 factor FOS, ${ }^{51}$ ). Data are also available from non-neural cell types for KLF6, ${ }^{41}$ STAT3, ${ }^{33}$ SMAD1, MYC, KLF4, ${ }^{15}$ JUN, ${ }^{46}$ and ATF3. ${ }^{91}$ Thus, until neuron-specific datasets are developed, these data may serve as first-pass indicators of potential co-occupancy relationships for RAG TFs.

Second, because the majority of TF binding sites occur at great distances from transcription start sites, an ongoing challenge in all fields is to identify which of these sites correspond to genuine cisregulatory (e.g. enhancer) regions. To date, no features of the primary DNA sequence have been identified that can reliably distinguish enhancers from non-regulatory regions. Instead, biochemical signatures specific to enhancers have been used. For instance,

Neuroscience Letters, (December 2016). DOI. This article is (C) Elsevier and permission has been granted for this version to appear in e-Publications@Marquette. Elsevier does not grant permission for this article to be further copied/distributed or hosted elsewhere without the express permission from Elsevier. 
enhancer regions tend to be nucleosome depleted, so one approach involves profiling chromatin accessibility genome-wide using DNAaseseq, ${ }^{21}$ or the more recent ATAC-Seq. ${ }^{19}$ For a more targeted approach, presence of histone marks such as $\mathrm{H} 3 \mathrm{~K} 4 \mathrm{me} 1^{32}$ or $\mathrm{H} 3 \mathrm{~K} 27 \mathrm{Ac},{ }^{18}$ and binding by regulatory factors like $\mathrm{p} 300,12,52,80$ or even binding by specific TFs $^{20}$ have been used to predict enhancer function across the genome, with varying success. Although a great majority of genomewide efforts to identify enhancer regions have been performed in nonneuronal cell types, genome-wide sequencing for a battery of promoter and enhancer specific histone marks have been carried out on brain tissue derived from embryonic mice as part of the ENCODE project $^{1}$ (https://www.encodeproject.org) and on adult brain tissue as part of the Roadmap epigenomics project ${ }^{8}$

(http://www.roadmapepigenomics.org). A major caveat to using these datasets is that the heterogeneous source material likely dilutes the signatures of specific cell types. In silico platforms exist to tackle this issue, in which binding profiles/expression profiles are tested against profiles from cell-type specific genes, to correlate which cell-type best represents the mixed-cell dataset. ${ }^{25,40}$

Finally, once enhancer regions are identified, their tremendous distance from gene loci creates ambiguity regarding the gene(s) under regulation. Although the assumption is often made that the relevant enhancers are those located nearest to a gene of interest, this assumption is debatable. ${ }^{88}$ In summary, although progress in other fields illustrates the tremendous potential of co-occupancy analysis to reveal TF-TF interactions of importance to regenerative neuroscience, development of this approach must await basic information regarding the distribution of TF binding, enhancers active in neurons, and perhaps clearer mapping of enhancers to gene loci.

\subsection{Implications for therapy}

Strategies to select optimal combinations of TFs will be strongly influenced by the specific mechanisms through which co-occupying TFs influence transcription. At one extreme, TFs could be considered to make additive contributions to similar processes, either positively or negatively. ${ }^{63}$ For instance, each individual factor could be partially effective at displacing nucleosomes, adding or removing epigenetic

Neuroscience Letters, (December 2016). DOI. This article is @ Elsevier and permission has been granted for this version to appear in e-Publications@Marquette. Elsevier does not grant permission for this article to be further copied/distributed or hosted elsewhere without the express permission from Elsevier. 
marks that favor activity, or recruiting a common set of activators or repressors. In this model, TFs are effectively functionally interchangeable, and the strategy for optimal manipulation is relatively straightforward. Once regulatory elements and their bound TFs are identified, this model would favor simultaneous expression of the maximal number of transcriptional activators and/or maximal knockdown of transcriptional repressors.

A very different picture emerges when considering the likelihood that co-occupying TFs achieve functional synergy by regulating diverse and complementary aspects of transcriptional activation. That is, some TFs may primarily modify epigenetic marks, others may enhance accessibility through chromatin bending, and others may recruit specific co-factors. An important implication of this model is that priming of chromatin by one TF could be a pre-requisite for recruitment of others. Indeed, an emerging concept in stem cell biology is that some TFs act as so-called "pioneer factors" and play an essential role in accessing closed chromatin and remodeling it to allow subsequent binding by additional TFs. ${ }^{34,71,72}$ An interesting example comes from genome-wide profiling of chromatin accessibility and cooccupancy of AP1 and Glucocorticoid receptor (GR). This study revealed that AP1 binding preceded GR binding, creating an accessible chromatin state around critical genomic loci, and was essential for subsequent GR binding and activity. ${ }^{9}$

The first implication of this model is that when selecting TF combinations for maximal effect, what matters most is not the number of TFs but rather the diversity of mechanisms that can be engaged. The issue of chromatin accessibility is particularly important, as single or even sets of TFs that normally target important regulatory regions may be unable to do so without appropriate chromatin remodeling factors. Overall, careful consideration of TFs that confer complementary activities, and particular attention to including TFs that assist in targeted opening of chromatin, may be an effective strategy to select functional sets of TFs for axon growth.

A second implication is that issues of timing and sequence must also be considered. It is clear that in some cases, complementary transcriptional mechanisms must be engaged in a strict order. For example, pioneer factors must precede other TFs in order to prepare

Neuroscience Letters, (December 2016). DOI. This article is @ Elsevier and permission has been granted for this version to appear in e-Publications@Marquette. Elsevier does not grant permission for this article to be further copied/distributed or hosted elsewhere without the express permission from Elsevier. 
the chromatin landscape for subsequent binding, and significant delays can exist between the onset of pioneer expression and appropriate chromatin remodeling. Thus synergistic effects may not be evident from TF/pioneer co-expression in short-term assays. An additional challenge is that in some cases early-acting TFs must be silenced before later-acting factors can be effective. For example, Sox family members, including the RAG TF SOX11, must be up- and downregulated in strict sequence during early neural differentiation. ${ }^{7}$ First, SOX3 binds widely to the genome of neural progenitor cells and acts to alter epigenetic marks. As the progenitor cells differentiate into neurons, SOX3 is downregulated and SOX11, which drives early expression of neural-specific genes important for axon growth, is upregulated. Interestingly, although SOX3 promotes epigenetic remodeling that facilitates subsequent SOX11 activity, it also physically competes with SOX11 to occlude binding; downregulation of SOX3 is essential for subsequent SOX11 activity. In other words, SOX3 and SOX11 cooperate to activate genes involved in axon growth, but in a manner that requires SOX3 expression to precede SOX11, and critically, to be transient. Thus prolonged co-expression of both factors, which is typical of many common gene delivery techniques, would not be optimal in this case.

Recent advances offer unprecedented opportunities to answer questions regarding the role of timing and sequence in transcriptional output. For example, the GAVPO system, based on light-triggered dimerization of DNA-binding domains, allows tight control of both the timing and amount of transgene expression. ${ }^{84}$ In one relevant application, GAVPO was used to control Brn2 expression in embryonic stem cells, in order to query how timing and dose affect the regulatory network of pluripotency TFs. ${ }^{70}$ Alternatively, multiple groups have engineered DNA binding motifs and functional domains such that their association can be controlled optically. ${ }^{39,61,64}$ When delivered to cells these constructs enable tight temporal control of transcriptional activity, transcriptional repression, or targeted epigenetic modifications. ${ }^{39,45,61}$ Thus in principle, multiple TFs can be delivered to neurons, with the expression or function of one or more factors regulated by optical stimulation. In this way, by systematically varying optical stimulation while quantifying rates of axon growth, it should be possible to determine how the timing and duration of expression of specific members of multi-TF sets impacts cooperative function.

Neuroscience Letters, (December 2016). DOI. This article is @ Elsevier and permission has been granted for this version to appear in e-Publications@Marquette. Elsevier does not grant permission for this article to be further copied/distributed or hosted elsewhere without the express permission from Elsevier. 


\section{Conclusions and future prospects}

It is likely that multiple, interactive transcriptional programs must be engaged to restore full regenerative potential in CNS neurons. How to identify the optimal set of factors, and how to optimally deliver these factors once identified, are core questions. Progress in other fields provides a conceptual framework to classify TF interactions, and provides a roadmap for progress in regenerative neuroscience. Techniques are available to establish physical, transcriptional, signaling, and co-occupancy relationships between TFs. Applying these to neural cell types, with particular attention paid to comparing regeneration-competent and -incompetent states, will establish transcription factor regulatory networks that underlie axon growth. In turn, these networks can be targeted using strategies driven by the specifics of the identified interactions (tethered constructs, mutant forms, complementary epigenetic functions, etc.). Although applying this framework to neurons entails considerable effort, it promises rapid progress in clarifying and leveraging TF interactions for functional gain after CNS injury.

\section{Conflict of interest}

None.

\section{Acknowledgements}

This work was supported by grants from NIHR21NS093278, NIH R01NS083983, Bryon Riesch Paralysis Foundation and Craig. H. Nielsen Foundation.

\section{References}

${ }^{1}$ An integrated encyclopedia of DNA elements in the human genome. Nature, 489 (2012), pp. 57-74

${ }^{2}$ G.D. Amoutzias, D.L. Robertson, Y. Van de Peer, S.G. Oliver. Choose your partners: dimerization in eukaryotic transcription factors. Trends Biochem. Sci., 33 (2008), pp. 220-229

Neuroscience Letters, (December 2016). DOI. This article is @ Elsevier and permission has been granted for this version to appear in e-Publications@Marquette. Elsevier does not grant permission for this article to be further copied/distributed or hosted elsewhere without the express permission from Elsevier. 
NOT THE PUBLISHED VERSION; this is the author's final, peer-reviewed manuscript. The published version may be accessed by following the link in the citation at the bottom of the page.

${ }^{3}$ A. Apara, J.L. Goldberg. Molecular mechanisms of the suppression of axon regeneration by KLF transcription factors. Neural Regen. Res., 9 (2014), pp. 1418-1421

${ }^{4}$ L. Bakiri, K. Matsuo, M. Wisniewska, E.F. Wagner, M. Yaniv. Promoter specificity and biological activity of tethered AP-1 dimers. Mol. Cell. Biol., 22 (2002), pp. 4952-4964

${ }^{5}$ F.M. Bareyre, N. Garzorz, C. Lang, T. Misgeld, H. Buning, M. Kerschensteiner. In vivo imaging reveals a phase-specific role of STAT3 during central and peripheral nervous system axon regeneration. Proc. Natl. Acad. Sci. U. S. A., 108 (2011), pp. 62826287

${ }^{6}$ S. Belin, H. Nawabi, C. Wang, S. Tang, A. Latremoliere, P. Warren, H. Schorle, C. Uncu, C.J. Woolf, Z. He, J.A. Steen. Injury-induced decline of intrinsic regenerative ability revealed by quantitative proteomics. Neuron, 86 (2015), pp. 1000-1014

${ }^{7}$ M. Bergsland, D. Ramskold, C. Zaouter, S. Klum, R. Sandberg, J. Muhr. Sequentially acting Sox transcription factors in neural lineage development. Genes Dev., 25 (2011), pp. 2453-2464

${ }^{8}$ B.E. Bernstein, J.A. Stamatoyannopoulos, J.F. Costello, B. Ren, A. Milosavljevic, A. Meissner, M. Kellis, M.A. Marra, A.L. Beaudet, J.R. Ecker, P.J. Farnham, M. Hirst, E.S. Lander, T.S. Mikkelsen, J.A. Thomson. The NIH roadmap epigenomics mapping consortium. Nat. Biotechnol., 28 (2010), pp. 1045-1048

${ }^{9}$ S.C. Biddie, S. John, P.J. Sabo, R.E. Thurman, T.A. Johnson, R.L. Schiltz, T.B. Miranda, M.H. Sung, S. Trump, S.L. Lightman, C. Vinson, J.A. Stamatoyannopoulos, G.L. Hager. Transcription factor AP1 potentiates chromatin accessibility and glucocorticoid receptor binding. Mol. Cell, 43 (2011), pp. 145-155

${ }^{10}$ M.G. Blackmore. Molecular control of axon growth: insights from comparative gene profiling and high-throughput screening. Int. Rev. Neurobiol., 105 (2012), pp. 39-70

${ }^{11}$ M.G. Blackmore, Z. Wang, J.K. Lerch, D. Motti, Y.P. Zhang, C.B. Shields, J.K. Lee, J.L. Goldberg, V.P. Lemmon, J.L. Bixby. Kruppel-like Factor 7 engineered for transcriptional activation promotes axon regeneration in the adult corticospinal tract. Proc. Natl. Acad. Sci. U. S. A., 109 (2012), pp. 7517-7522

${ }^{12}$ M.J. Blow, D.J. McCulley, Z. Li, T. Zhang, J.A. Akiyama, A. Holt, I. PlajzerFrick, M. Shoukry, C. Wright, F. Chen, V. Afzal, J. Bristow, B. Ren, B.L. Black, E.M. Rubin, A. Visel, L.A. Pennacchio. ChIP-Seq identification of weakly conserved heart enhancers. Nat. Genet., 42 (2010), pp. 806810

${ }^{13}$ V. Chandran, G. Coppola, H. Nawabi, T. Omura, R. Versano, E.A. Huebner, A. Zhang, M. Costigan, A. Yekkirala, L. Barrett, A. Blesch, I.

Neuroscience Letters, (December 2016). DOI. This article is @ Elsevier and permission has been granted for this version to appear in e-Publications@Marquette. Elsevier does not grant permission for this article to be further copied/distributed or hosted elsewhere without the express permission from Elsevier. 
Michaelevski, J. Davis-Turak, F. Gao, P. Langfelder, S. Horvath, Z. He, L. Benowitz, M. Fainzilber, M. Tuszynski, C.J. Woolf, D.H. Geschwind. A systems-level analysis of the peripheral nerve intrinsic axonal growth program. Neuron, 89 (2016), pp. 956-970

${ }^{14}$ A. Chatr-Aryamontri, B.J. Breitkreutz, R. Oughtred, L. Boucher, S. Heinicke, D. Chen, C. Stark, A. Breitkreutz, N. Kolas, L. O'Donnell, T. Reguly, J. Nixon, L. Ramage, A. Winter, A. Sellam, C. Chang, J. Hirschman, C. Theesfeld, J. Rust, M.S. Livstone, K. Dolinski, M. Tyers. The BioGRID interaction database: 2015 update. Nucleic Acids Res., 43 (2015), pp. D470-478

${ }^{15}$ X. Chen, H. Xu, P. Yuan, F. Fang, M. Huss, V.B. Vega, E. Wong, Y.L. Orlov, W. Zhang, J. Jiang, Y.H. Loh, H.C. Yeo, Z.X. Yeo, V. Narang, K.R. Govindarajan, B. Leong, A. Shahab, Y. Ruan, G. Bourque, W.K. Sung, N.D. Clarke, C.L. Wei, H.H. Ng. Integration of external signaling pathways with the core transcriptional network in embryonic stem cells. Cell, 133 (2008), pp. 1106-1117

${ }^{16}$ Y. Cho, J.E. Shin, E.E. Ewan, Y.M. Oh, W. Pita-Thomas, V. Cavalli. Activating injury-responsive genes with hypoxia enhances axon regeneration through neuronal HIF-1alpha. Neuron, 88 (2015), pp. 720-734

17].M. Cregg, M.A. DePaul, A.R. Filous, B.T. Lang, A. Tran, J. Silver. Functional regeneration beyond the glial scar. Exp. Neurol., 253 (2014), pp. 197207

${ }^{18}$ M.P. Creyghton, A.W. Cheng, G.G. Welstead, T. Kooistra, B.W. Carey, E.J. Steine, J. Hanna, M.A. Lodato, G.M. Frampton, P.A. Sharp, L.A. Boyer, R.A. Young, R. Jaenisch. Histone H3K27ac separates active from poised enhancers and predicts developmental state. Proc. Natl. Acad. Sci. U. S. A., 107 (2010), pp. 21931-21936

${ }^{19} \mathrm{~K}$. Davie, J. Jacobs, M. Atkins, D. Potier, V. Christiaens, G. Halder, S. Aerts. Discovery of transcription factors and regulatory regions driving in vivo tumor development by ATAC-seq and FAIRE-seq open chromatin profiling. PLoS Genet., 11 (2015), p. e1004994

${ }^{20}$ N. Dogan, W. Wu, C.S. Morrissey, K.B. Chen, A. Stonestrom, M. Long, C.A. Keller, Y. Cheng, D. Jain, A. Visel, L.A. Pennacchio, M.J. Weiss, G.A. Blobel, R.C. Hardison. Occupancy by key transcription factors is a more accurate predictor of enhancer activity than histone modifications or chromatin accessibility. Epigenet. Chromatin, 8 (2015), p. 16

${ }^{21}$ M.O. Dorschner, M. Hawrylycz, R. Humbert, J.C. Wallace, A. Shafer, J. Kawamoto, J. Mack, R. Hall, J. Goldy, P.J. Sabo, A. Kohli, Q. Li, M. McArthur, J.A. Stamatoyannopoulos. High-throughput localization of functional elements by quantitative chromatin profiling. Nat. Methods, 1 (2004), pp. 219-225

Neuroscience Letters, (December 2016). DOI. This article is (C) Elsevier and permission has been granted for this version to appear in e-Publications@Marquette. Elsevier does not grant permission for this article to be further copied/distributed or hosted elsewhere without the express permission from Elsevier. 
NOT THE PUBLISHED VERSION; this is the author's final, peer-reviewed manuscript. The published version may be accessed by following the link in the citation at the bottom of the page.

${ }^{22}$ N.D. Fagoe, C.L. Attwell, D. Kouwenhoven, J. Verhaagen, M.R. Mason. Overexpression of ATF3 or the combination of ATF3, c-Jun STAT3 and Smad1 promotes regeneration of the central axon branch of sensory neurons but without synergistic effects. Hum. Mol. Genet., 24 (2015), pp. 6788-6800

${ }^{23}$ J.V. Falvo, D. Thanos, T. Maniatis. Reversal of intrinsic DNA bends in the IFN beta gene enhancer by transcription factors and the architectural protein HMG I(Y). Cell, 83 (1995), pp. 1101-1111

${ }^{24}$ A. Franceschini, D. Szklarczyk, S. Frankild, M. Kuhn, M. Simonovic, A. Roth, J. Lin, P. Minguez, P. Bork, C. von Mering, L.J. Jensen. STRING v9.1: protein-protein interaction networks, with increased coverage and integration. Nucleic Acids Res., 41 (2013), pp. D808-815

${ }^{25}$ C.L. Frank, F. Liu, R. Wijayatunge, L. Song, M.T. Biegler, M.G. Yang, C.M. Vockley, A. Safi, C.A. Gersbach, G.E. Crawford, A.E. West. Regulation of chromatin accessibility and Zic binding at enhancers in the developing cerebellum. Nat. Neurosci., 18 (2015), pp. 647-656

${ }^{26}$ M.S. Gadd, M. Bhati, C.M. Jeffries, D.B. Langley, J. Trewhella, J.M. Guss, J.M. Matthews. Structural basis for partial redundancy in a class of transcription factors the LIM homeodomain proteins, in neural cell type specification. J. Biol. Chem., 286 (2011), pp. 42971-42980

${ }^{27}$ Y. Gao, K. Deng, J. Hou, J.B. Bryson, A. Barco, E. Nikulina, T. Spencer, W. Mellado, E.R. Kandel, M.T. Filbin. Activated CREB is sufficient to overcome inhibitors in myelin and promote spinal axon regeneration in vivo. Neuron, 44 (2004), pp. 609-621

28M.B. Gerstein, A. Kundaje, M. Hariharan, S.G. Landt, K.K. Yan, C. Cheng, X.J. Mu, E. Khurana, J. Rozowsky, R. Alexander, R. Min, P. Alves, A. Abyzov, N. Addleman, N. Bhardwaj, A.P. Boyle, P. Cayting, A. Charos, D.Z. Chen, Y. Cheng, D. Clarke, C. Eastman, G. Euskirchen, S. Frietze, Y. Fu, J. Gertz, F. Grubert, A. Harmanci, P. Jain, M. Kasowski, P. Lacroute, J. Leng, J. Lian, H. Monahan, H. O'Geen, Z. Ouyang, E.C. Partridge, D. Patacsil, F. Pauli, D. Raha, L. Ramirez, T.E. Reddy, B. Reed, M. Shi, T. Slifer, J. Wang, L. Wu, X. Yang, K.Y. Yip, G. Zilberman-Schapira, S. Batzoglou, A. Sidow, P.J. Farnham, R.M. Myers, S.M. Weissman, M. Snyder. Architecture of the human regulatory network derived from ENCODE data. Nature, 489 (2012), pp. 91-100

${ }^{29}$ D.K. Goode, N. Obier, M.S. Vijayabaskar, A.L.M. Lie, A.J. Lilly, R. Hannah, M. Lichtinger, K. Batta, M. Florkowska, R. Patel, M. Challinor, K. Wallace, J. Gilmour, S.A. Assi, P. Cauchy, M. Hoogenkamp, D.R. Westhead, G. Lacaud, V. Kouskoff, B. Gottgens, C. Bonifer. Dynamic gene regulatory networks drive hematopoietic specification and differentiation. Dev. Cell, 36 (2016), pp. 572-587

Neuroscience Letters, (December 2016). DOI. This article is (C) Elsevier and permission has been granted for this version to appear in e-Publications@Marquette. Elsevier does not grant permission for this article to be further copied/distributed or hosted elsewhere without the express permission from Elsevier. 
NOT THE PUBLISHED VERSION; this is the author's final, peer-reviewed manuscript. The published version may be accessed by following the link in the citation at the bottom of the page.

30]. Hall, G. Guo, J. Wray, I. Eyres, J. Nichols, L. Grotewold, S. Morfopoulou, P. Humphreys, W. Mansfield, R. Walker, S. Tomlinson, A. Smith. Oct4 and LIF/Stat3 additively induce Kruppel factors to sustain embryonic stem cell self-renewal. Cell Stem Cell, 5 (2009), pp. 597-609

${ }^{31}$ H. Han, H. Shim, D. Shin, J.E. Shim, Y. Ko, J. Shin, H. Kim, A. Cho, E. Kim, T. Lee, K. Kim, S. Yang, D. Bae, A. Yun, S. Kim, C.Y. Kim, H.J. Cho, B. Kang, S. Shin, I. Lee. TRRUST: a reference database of human transcriptional regulatory interactions. Sci. Rep., 5 (2015), p. 11432

${ }^{32}$ N.D. Heintzman, R.K. Stuart, G. Hon, Y. Fu, C.W. Ching, R.D. Hawkins, L.O. Barrera, S. Van Calcar, C. Qu, K.A. Ching, W. Wang, Z. Weng, R.D. Green, G.E. Crawford, B. Ren. Distinct and predictive chromatin signatures of transcriptional promoters and enhancers in the human genome. Nat. Genet., 39 (2007), pp. 311-318

${ }^{33}$ A.P. Hutchins, S. Poulain, D. Miranda-Saavedra. Genome-wide analysis of STAT3 binding in vivo predicts effectors of the anti-inflammatory response in macrophages. Blood, 119 (2012), pp. e110-119

${ }^{34} \mathrm{M}$. Iwafuchi-Doi, K.S. Zaret. Pioneer transcription factors in cell reprogramming. Genes Dev., 28 (2014), pp. 2679-2692

${ }^{35}$ M.P. Jankowski, S.L. McIlwrath, X. Jing, P.K. Cornuet, K.M. Salerno, H.R. Koerber, K.M. Albers. Sox11 transcription factor modulates peripheral nerve regeneration in adult mice. Brain Res., 1256 (2009), pp. 43-54

${ }^{36}$ C. Jiang, J.H. Kim, F. Li, A. Qu, O. Gavrilova, Y.M. Shah, F.J. Gonzalez. Hypoxia-inducible factor 1alpha regulates a SOCS3-STAT3-adiponectin signal transduction pathway in adipocytes. J. Biol. Chem., 288 (2013), pp. 3844-3857

${ }^{37}$ D. Jin, Y. Liu, F. Sun, X. Wang, X. Liu, Z. He. Restoration of skilled locomotion by sprouting corticospinal axons induced by co-deletion of PTEN and SOCS3. Nat. Commun., 6 (2015), p. 8074

38]. Kawauchi, C. Zhang, K. Nobori, Y. Hashimoto, M.T. Adachi, A. Noda, M. Sunamori, S. Kitajima. Transcriptional repressor activating transcription factor 3 protects human umbilical vein endothelial cells from tumor necrosis factor-alpha-induced apoptosis through downregulation of p53 transcription. J. Biol. Chem., 277 (2002), pp. 3902539034

${ }^{39}$ S. Konermann, M.D. Brigham, A.E. Trevino, P.D. Hsu, M. Heidenreich, L. Cong, R.J. Platt, D.A. Scott, G.M. Church, F. Zhang. Optical control of mammalian endogenous transcription and epigenetic states. Nature, 500 (2013), pp. 472-476

${ }^{40}$ V. Kumar, M. Muratani, N.A. Rayan, P. Kraus, T. Lufkin, H.H. Ng, S. Prabhakar. Uniform, optimal signal processing of mapped deepsequencing data. Nat. Biotechnol., 31 (2013), pp. 615-622

${ }^{41}$ B.M. Laitman, L. Asp, J.N. Mariani, J. Zhang, J. Liu, S. Sawai, C. Chapouly, S. Horng, E.G. Kramer, N. Mitiku, H. Loo, N. Burlant, X. Pedre, Y.

Neuroscience Letters, (December 2016). DOI. This article is @ Elsevier and permission has been granted for this version to appear in e-Publications@Marquette. Elsevier does not grant permission for this article to be further copied/distributed or hosted elsewhere without the express permission from Elsevier. 
Hara, G. Nudelman, E. Zaslavsky, Y.M. Lee, D.A. Braun, Q.R. Lu, G. Narla, C.S. Raine, S.L. Friedman, P. Casaccia, G.R. John. The transcriptional activator Kruppel-like factor- 6 is required for CNS myelination. PLoS Biol., 14 (2016), p. e1002467

${ }^{42}$ C. Lang, P.M. Bradley, A. Jacobi, M. Kerschensteiner, F.M. Bareyre. STAT3 promotes corticospinal remodelling and functional recovery after spinal cord injury. EMBO Rep., 14 (2013), pp. 931-937

${ }^{43}$ S. Lee, R. Shen, H.H. Cho, R.J. Kwon, S.Y. Seo, J.W. Lee, S.K. Lee. STAT3 promotes motor neuron differentiation by collaborating with motor neuron-specific LIM complex. Proc. Natl. Acad. Sci. U. S. A., 110 (2013), pp. 11445-11450

${ }^{44}$ L. Licata, L. Briganti, D. Peluso, L. Perfetto, M. Iannuccelli, E. Galeota, F. Sacco, A. Palma, A.P. Nardozza, E. Santonico, L. Castagnoli, G. Cesareni. MINT, the molecular interaction database: 2012 update. Nucleic Acids Res., 40 (2012), pp. D857-861

${ }^{45} \mathrm{H}$. Liu, G. Gomez, S. Lin, C. Lin. Optogenetic control of transcription in zebrafish. PLoS One, 7 (2012), p. e50738

${ }^{46}$ J. Liu, Q. Han, T. Peng, M. Peng, B. Wei, D. Li, X. Wang, S. Yu, J. Yang, S. Cao, K. Huang, A.P. Hutchins, H. Liu, J. Kuang, Z. Zhou, J. Chen, H. Wu, L. Guo, Y. Chen, X. Li, B. Liao, W. He, H. Song, H. Yao, G. Pan, D. Pei. The oncogene c-Jun impedes somatic cell reprogramming. Nat. Cell Biol., 17 (2015), pp. 856-867

${ }^{47}$ K. Liu, A. Tedeschi, K.K. Park, Z. He. Neuronal intrinsic mechanisms of axon regeneration. Annu. Rev. Neurosci., 34 (2011), pp. 131-152

${ }^{48} \mathrm{~K}$. Low, A. Blesch, J. Herrmann, M.H. Tuszynski. A dual promoter lentiviral vector for the in vivo evaluation of gene therapeutic approaches to axon regeneration after spinal cord injury. Gene Ther., 17 (2010), pp. 577-591

${ }^{49}$ X. Luo, M. Ribeiro, E.R. Bray, D.H. Lee, B.J. Yungher, S.T. Mehta, K.A. Thakor, F. Diaz, J.K. Lee, C.T. Moraes, J.L. Bixby, V.P. Lemmon, K.K. Park. Enhanced transcriptional activity and mitochondrial localization of STAT3 Co-induce axon regrowth in the adult central nervous system. Cell Rep., 15 (2016), pp. 398-410

${ }^{50} \mathrm{P}$. Machanick, T.L. Bailey. MEME-ChIP: motif analysis of large DNA datasets. Bioinformatics, 27 (2011), pp. 1696-1697

${ }^{51}$ A.N. Malik, T. Vierbuchen, M. Hemberg, A.A. Rubin, E. Ling, C.H. Couch, H. Stroud, I. Spiegel, K.K. Farh, D.A. Harmin, M.E. Greenberg. Genomewide identification and characterization of functional neuronal activitydependent enhancers. Nat. Neurosci., 17 (2014), pp. 1330-1339

${ }^{52}$ D. May, M.J. Blow, T. Kaplan, D.J. McCulley, B.C. Jensen, J.A. Akiyama, A. Holt, I. Plajzer-Frick, M. Shoukry, C. Wright, V. Afzal, P.C. Simpson, E.M. Rubin, B.L. Black, J. Bristow, L.A. Pennacchio, A. Visel. Large-

Neuroscience Letters, (December 2016). DOI. This article is @ Elsevier and permission has been granted for this version to appear in e-Publications@Marquette. Elsevier does not grant permission for this article to be further copied/distributed or hosted elsewhere without the express permission from Elsevier. 
scale discovery of enhancers from human heart tissue. Nat. Genet., 44 (2012), pp. 89-93

${ }^{53}$ M. Merika, A.J. Williams, G. Chen, T. Collins, D. Thanos. Recruitment of $\mathrm{CBP} / \mathrm{p} 300$ by the IFN beta enhanceosome is required for synergistic activation of transcription. Mol. Cell, 1 (1998), pp. 277-287

${ }^{54}$ J.A. Miller, J. Widom. Collaborative competition mechanism for gene activation in vivo. Mol. Cell. Biol., 23 (2003), pp. 1623-1632

${ }^{55} \mathrm{~K}$. Mitsouras, B. Wong, C. Arayata, R.C. Johnson, M. Carey. The DNA architectural protein HMGB1 displays two distinct modes of action that promote enhanceosome assembly. Mol. Cell. Biol., 22 (2002), pp. 4390-4401

${ }^{56}$ D.L. Moore, M.G. Blackmore, Y. Hu, K.H. Kaestner, J.L. Bixby, V.P. Lemmon, J.L. Goldberg. KLF family members regulate intrinsic axon regeneration ability. Science, 326 (2009), pp. 298-301

${ }^{57}$ D.L. Moore, J.L. Goldberg. Multiple transcription factor families regulate axon growth and regeneration. Dev. Neurobiol., 71 (2011), pp. 11861211

${ }^{58} \mathrm{~N}$. Muraoka, M. Ieda. Stoichiometry of transcription factors is critical for cardiac reprogramming. Circ. Res., 116 (2015), pp. 216-218

${ }^{59}$ Y. Nakai-Futatsugi, H. Niwa. Transcription factor network in embryonic stem cells: heterogeneity under the stringency. Biol. Pharm. Bull., 36 (2013), pp. 166-170

${ }^{60} \mathrm{~S}$. Orchard, M. Ammari, B. Aranda, L. Breuza, L. Briganti, F. BroackesCarter, N.H. Campbell, G. Chavali, C. Chen, N. del-Toro, M. Duesbury, M. Dumousseau, E. Galeota, U. Hinz, M. Iannuccelli, S. Jagannathan, R. Jimenez, J. Khadake, A. Lagreid, L. Licata, R.C. Lovering, B. Meldal, A.N. Melidoni, M. Milagros, D. Peluso, L. Perfetto, P. Porras, A. Raghunath, S. Ricard-Blum, B. Roechert, A. Stutz, M. Tognolli, K. van Roey, G. Cesareni, H. Hermjakob. The MIntAct project-IntAct as a common curation platform for 11 molecular interaction databases. Nucleic Acids Res., 42 (2014), pp. D358-D363

${ }^{61}$ F. Paonessa, S. Criscuolo, S. Sacchetti, D. Amoroso, H. Scarongella, F. Pecoraro Bisogni, E. Carminati, G. Pruzzo, L. Maragliano, F. Cesca, F. Benfenati. Regulation of neural gene transcription by optogenetic inhibition of the RE1-silencing transcription factor. Proc. Natl. Acad. Sci. U. S. A., 113 (2016), pp. E91-100

${ }^{62}$ P. Parikh, Y. Hao, M. Hosseinkhani, S.B. Patil, G.W. Huntley, M. TessierLavigne, H. Zou. Regeneration of axons in injured spinal cord by activation of bone morphogenetic protein/Smad1 signaling pathway in adult neurons. Proc. Natl. Acad. Sci. U. S. A., 108 (2011), pp. E99107

${ }^{63}$ P. Perez-Pinera, D.G. Ousterout, J.M. Brunger, A.M. Farin, K.A. Glass, F. Guilak, G.E. Crawford, A.J. Hartemink, C.A. Gersbach. Synergistic and

Neuroscience Letters, (December 2016). DOI. This article is @ Elsevier and permission has been granted for this version to appear in e-Publications@Marquette. Elsevier does not grant permission for this article to be further copied/distributed or hosted elsewhere without the express permission from Elsevier. 
tunable human gene activation by combinations of synthetic transcription factors. Nat. Methods, 10 (2013), pp. 239-242

${ }^{64}$ L.R. Polstein, C.A. Gersbach. Light-inducible spatiotemporal control of gene activation by customizable zinc finger transcription factors. J. Am. Chem. Soc., 134 (2012), pp. 16480-16483

${ }^{65}$ G. Raivich, M. Bohatschek, C. Da Costa, O. Iwata, M. Galiano, M. Hristova, A.S. Nateri, M. Makwana, L. Riera-Sans, D.P. Wolfer, H.P. Lipp, A. Aguzzi, E.F. Wagner, A. Behrens. The AP-1 transcription factor C-Jun is required for efficient axonal regeneration. Neuron, 43 (2004), pp. 5767

${ }^{66}$ Saijilafu, E.M. Hur, F.Q. Zhou. Genetic dissection of axon regeneration via in vivo electroporation of adult mouse sensory neurons. Nat. Commun., 2 (2011), p. 543

${ }^{67}$ R. Seijffers, C.D. Mills, C.J. Woolf. ATF3 increases the intrinsic growth state of DRG neurons to enhance peripheral nerve regeneration. $J$.

Neurosci., 27 (2007), pp. 7911-7920

${ }^{68}$ B.T. Selvaraj, N. Frank, F.L. Bender, E. Asan, M. Sendtner. Local axonal function of STAT3 rescues axon degeneration in the pmn model of motoneuron disease. J. Cell Biol., 199 (2012), pp. 437-451

${ }^{69}$ P.D. Smith, F. Sun, K.K. Park, B. Cai, C. Wang, K. Kuwako, I. MartinezCarrasco, L. Connolly, Z. He. SOCS3 deletion promotes optic nerve regeneration in vivo. Neuron, 64 (2009), pp. 617-623

${ }^{70}$ C. Sokolik, Y. Liu, D. Bauer, J. McPherson, M. Broeker, G. Heimberg, L.S. Qi, D.A. Sivak, M. Thomson. Transcription factor competition allows embryonic stem cells to distinguish authentic signals from noise. Cell Syst., 1 (2015), pp. 117-129

${ }^{71}$ A. Soufi, G. Donahue, K.S. Zaret. Facilitators and impediments of the pluripotency reprogramming factors' initial engagement with the genome. Cell, 151 (2012), pp. 994-1004

${ }^{72}$ A. Soufi, M.F. Garcia, A. Jaroszewicz, N. Osman, M. Pellegrini, K.S. Zaret. Pioneer transcription factors target partial DNA motifs on nucleosomes to initiate reprogramming. Cell, 161 (2015), pp. 555-568

${ }^{73}$ F. Sun, K.K. Park, S. Belin, D. Wang, T. Lu, G. Chen, K. Zhang, C. Yeung, G. Feng, B.A. Yankner, Z. He. Sustained axon regeneration induced by co-deletion of PTEN and SOCS3. Nature, 480 (2011), pp. 372-375

${ }^{74} \mathrm{~K}$. Takahashi, S. Yamanaka. Induction of pluripotent stem cells from mouse embryonic and adult fibroblast cultures by defined factors. Cell, 126 (2006), pp. 663-676

${ }^{75}$ W. Tang, I. Ehrlich, S.B. Wolff, A.M. Michalski, S. Wolfl, M.T. Hasan, A. Luthi, R. Sprengel. Faithful expression of multiple proteins via 2Apeptide self-processing: a versatile and reliable method for manipulating brain circuits. J. Neurosci., 29 (2009), pp. 8621-8629

Neuroscience Letters, (December 2016). DOI. This article is @ Elsevier and permission has been granted for this version to appear in e-Publications@Marquette. Elsevier does not grant permission for this article to be further copied/distributed or hosted elsewhere without the express permission from Elsevier. 
NOT THE PUBLISHED VERSION; this is the author's final, peer-reviewed manuscript. The published version may be accessed by following the link in the citation at the bottom of the page.

${ }^{76}$ M. Tarocchi, R. Hannivoort, Y. Hoshida, U.E. Lee, D. Vetter, G. Narla, A. Villanueva, M. Oren, J.M. Llovet, S.L. Friedman. Carcinogen-induced hepatic tumors in KLF6+/- mice recapitulate aggressive human hepatocellular carcinoma associated with p53 pathway deregulation. Hepatology, 54 (2011), pp. 522-531

${ }^{77} \mathrm{~A}$. Tedeschi. Tuning the orchestra: transcriptional pathways controlling axon regeneration. Front. Mol. Neurosci., 4 (2011), p. 60

${ }^{78}$ A. Tedeschi, T. Nguyen, R. Puttagunta, P. Gaub, S. Di Giovanni. A p53$\mathrm{CBP} / \mathrm{p} 300$ transcription module is required for GAP-43 expression, axon outgrowth, and regeneration. Cell Death Differ., 16 (2009), pp. 543-554

${ }^{79}$ R.E. van Kesteren, M.R. Mason, H.D. Macgillavry, A.B. Smit, J. Verhaagen. A gene network perspective on axonal regeneration. Front. Mol. Neurosci., 4 (2011), p. 46

${ }^{80}$ A. Visel, M.J. Blow, Z. Li, T. Zhang, J.A. Akiyama, A. Holt, I. Plajzer-Frick, M. Shoukry, C. Wright, F. Chen, V. Afzal, B. Ren, E.M. Rubin, L.A. Pennacchio. ChIP-seq accurately predicts tissue-specific activity of enhancers. Nature, 457 (2009), pp. 854-858

${ }^{81}$ T.C. Voss, R.L. Schiltz, M.H. Sung, P.M. Yen, J.A. Stamatoyannopoulos, S.C. Biddie, T.A. Johnson, T.B. Miranda, S. John, G.L. Hager. Dynamic exchange at regulatory elements during chromatin remodeling underlies assisted loading mechanism. Cell, 146 (2011), pp. 544-554

82]. Wang, J. Zhuang, S. Iyer, X. Lin, T.W. Whitfield, M.C. Greven, B.G. Pierce, X. Dong, A. Kundaje, Y. Cheng, O.J. Rando, E. Birney, R.M. Myers, W.S. Noble, M. Snyder, Z. Weng. Sequence features and chromatin structure around the genomic regions bound by 119 human transcription factors. Genome Res., 22 (2012), pp. 1798-1812

83]. Wang, J. Zhuang, S. Iyer, X.Y. Lin, M.C. Greven, B.H. Kim, J. Moore, B.G. Pierce, X. Dong, D. Virgil, E. Birney, J.H. Hung, Z. Weng.

Factorbook.org: a Wiki-based database for transcription factor-binding data generated by the ENCODE consortium. Nucleic Acids Res., 41 (2013), pp. D171-176

${ }^{84} \mathrm{X}$. Wang, X. Chen, Y. Yang. Spatiotemporal control of gene expression by a light-switchable transgene system. Nat. Methods, 9 (2012), pp. 266269

85Z. Wang, A. Reynolds, A. Kirry, C. Nienhaus, M.G. Blackmore. Overexpression of Sox11 promotes corticospinal tract regeneration after spinal injury while interfering with functional recovery. $J$. Neurosci., 35 (2015), pp. 3139-3145

${ }^{86} \mathrm{P}$. Wehler, D. Niopek, R. Eils, B. Di Ventura. Optogenetic control of nuclear protein import in living cells using light-Inducible nuclear localization signals (LINuS). Curr. Protoc. Chem. Biol., 8 (2016), pp. 131-145

Neuroscience Letters, (December 2016). DOI. This article is @ Elsevier and permission has been granted for this version to appear in e-Publications@Marquette. Elsevier does not grant permission for this article to be further copied/distributed or hosted elsewhere without the express permission from Elsevier. 
NOT THE PUBLISHED VERSION; this is the author's final, peer-reviewed manuscript. The published version may be accessed by following the link in the citation at the bottom of the page.

${ }^{87}$ R.R. Williams, I. Venkatesh, D.D. Pearse, A.J. Udvadia, M.B. Bunge. MASH1/Ascl1a leads to GAP43 expression and axon regeneration in the adult CNS. PLoS One, 10 (2015), p. e0118918

${ }^{88}$ N.K. Wilson, S.D. Foster, X. Wang, K. Knezevic, J. Schutte, P. Kaimakis, P.M. Chilarska, S. Kinston, W.H. Ouwehand, E. Dzierzak, J.E. Pimanda, M.F. de Bruijn, B. Gottgens. Combinatorial transcriptional control in blood stem/progenitor cells: genome-wide analysis of ten major transcriptional regulators. Cell Stem Cell, 7 (2010), pp. 532-544

${ }^{89}$ L. Yao, H. Shen, P.W. Laird, P.J. Farnham, B.P. Berman. Inferring regulatory element landscapes and transcription factor networks from cancer methylomes. Genome Biol., 16 (2015), p. 105

${ }^{90} \mathrm{C}$. Zhang, C. Gao, J. Kawauchi, Y. Hashimoto, N. Tsuchida, S. Kitajima. Transcriptional activation of the human stress-inducible transcriptional repressor ATF3 gene promoter by p53. Biochem. Biophys. Res. Commun., 297 (2002), pp. 1302-1310

91 J. Zhao, X. Li, M. Guo, J. Yu, C. Yan. The common stress responsive transcription factor ATF3 binds genomic sites enriched with p300 and H3K27ac for transcriptional regulation. BMC Genom., 17 (2016), p. 335

${ }^{92}$ L. Zhou, H.P. Too. Mitochondrial localized STAT3 is involved in NGF induced neurite outgrowth. PLoS One, 6 (2011), p. e21680

Corresponding author at: Department of Biomedical Sciences, Marquette University, Milwaukee, WI, 53201, USA.

\section{Appendix A. Supplementary data}

The following is Supplementary data to this article:

(C) 2016 Elsevier Ireland Ltd. All rights reserved.

Neuroscience Letters, (December 2016). DOI. This article is (C) Elsevier and permission has been granted for this version to appear in e-Publications@Marquette. Elsevier does not grant permission for this article to be further copied/distributed or hosted elsewhere without the express permission from Elsevier. 


\begin{tabular}{|c|c|c|c|c|c|c|c|}
\hline KLF4 & $\begin{array}{ll}1 & 2\end{array}$ & KLF4 & \multirow[b]{2}{*}{ KLF6/7 } & \multirow[b]{3}{*}{ ATF3 } & \multirow[b]{4}{*}{ JUN } & \multirow[b]{5}{*}{ p53 } & \multirow[b]{6}{*}{ SMAD1 } \\
\hline KLF6/7 & 44 & & & & & & \\
\hline ATF3 & 5 & & 17 & & & & \\
\hline JUN & 67 & & & $\mid \begin{array}{ll}20 & 22 \\
21 & 22\end{array}$ & & & \\
\hline p53 & 8 & 16 & $\begin{array}{ll}18 & 19\end{array}$ & $\begin{array}{l}23- \\
25\end{array} 26$ & 29 & & \\
\hline SMAD1 & 10 & & & & & 38 & \\
\hline MYC & 1112 & & & 7 & 30 & $\begin{array}{llll}40 & 39 & 7 & 41\end{array}$ & \\
\hline CREB & & & & 27 & 3132 & 42 & \\
\hline SoX11 & & & & 28 & & & 4647 \\
\hline MASH1 & & & & & & & \\
\hline HIF1a & $\begin{array}{lll}13 & 14 & 1\end{array}$ & & & & $\begin{array}{l}33- \\
34\end{array} 35$ & $\begin{array}{l}43 \\
45\end{array}$ & \\
\hline & STAT3 & KLF4 & KLF6/7 & ATF3 & JUN & p53 & SMAD1 \\
\hline
\end{tabular}

$1 \quad$ Hall et al.,2009 11 Valera et al.,2013

2 Qin et al.,2013 12 Kidder et al.,2008

21 Hai and Curran.,2001

Qin and Zhang, 13 Gray et al.,2005

22 Kim et al.,2014

$4 \quad$ Laitman et al.,2 14 Jiang et al.,2013

23 Yan et al.,2005

24 Yan et al.,2002

$5 \quad$ Grossman et al. 15 Marzec et al.,2011

25 Stelzl et al.,2005

Zhang et al.,19! 16 Zhang et al.,2000

26 Zhang et al.,2002

Griffon et al.,20 17 Huang et al.,2008

27 Zhang et al.,2011

Park et al.,2013 18 Tarocchi et al.,2011

28 Jankowski et al.,2009

38

Chen et al.,200\& 19 Rubenstein et al.,2004

29 Ginsberg et al.,1991

39

10

Nakashima et a 20 Li et al.,2015

30 Levy and Forman,2010

40 
Physical interaction

Transcriptional cross-regulation

Signalling cross-regulation

Co-occupancy

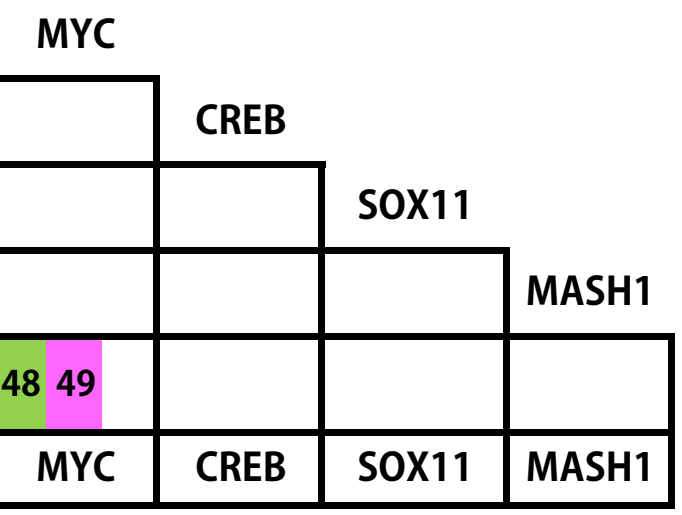

Benbrook and Jones, 1990

Herdegen and Leah,1998

Yu et al.,2009

Alfranca et al.,2002

Laderoute et al.,2002

Chau et al.,2012

Agarwal et al.,2010

Ben-Yosef et al.,1998

Slack et al.,2005

Giebler et al.,2000
41 Bae et al.,2002

42 Sanchez-puig et al.,2005

43 An et al.,1998

$44 \mathrm{Xu}$ et al.,2015

45 Vegliante et al.,2013

46 Koshiji et al.,2004

47 Doe et al.,2012 
